O'Bryant. HCA Healthcare Journal of Medicine (2021) 2:4.

https://doi.org/10.36518/2689-0216.1255

\title{
Poem
}

\section{Cachexia, Following Flowers}

Sinéad O’Bryant ${ }^{1}$

\section{Abstract}

\section{Description}

This poem explores a similar experience I once encountered working with an oncologist, as a patient learns about the recurrence of cancer after being in remission. The situation struck me as I felt the stir of human sadness and courage, and I would like to dedicate the poem to those living with cancer, who face the trepidation of their daily lives with bravery. What I hope this writing demonstrates is the depth and complexity of emotions felt by both patients and their physicians in times of bad news and expresses the beauty that underlies a strong and genuine patient-physician relationship.

\section{Keywords}

medicine in the arts; humanities; poetry; neoplasms; recurrence; remission induction; neoplastic processes; medical oncology; cancer; undergraduate medical education

The first thing I saw as we entered the room

was the pink of rhododendrons,

Petals drifting wayside to the floor,

Being held by a man with his wife

Grinning in earnest joy.

"One year! One year!

Not a drop of sickness in him!"

Thrusting over the florets

Together, they sang to us

a psalm of life with no cancer:

The glorious mystery of

Treatment however so sickly

Yielding way to the miracle

of dying pieces and parts

Becoming anew,

reconstructing what was left behind

In those intervals of such darkness

And giving way to a life

with every unit of time revered

Carefully in the palms of their hands.

The physician nodded, gracious for this kindness

And with crisp trepidation

Opened the CT scan images.

She inched her way through each slice

Until the bullet hit:

The keyboard mouse lightly traced an outline

Author affiliations are listed at the end of this article.

Correspondence to:

Sinéad O’Bryant

Mercer University School of

Medicine

1250 E 66th St.

Savannah, GA 31404

(11018190@live.mercer.edu) 
Infiltrating the liver, a lump completely of temporal horror, revealing the elasticity of time shooting back at the husband and wife.

It seemed as if I was watching cachexia occur In only a single moment, as this man Soaked in the certainty of his body's Own secrecy and betrayal.

The song strings of my breathlessness mixed with their shallow silence, as the physician spoke, composing a new way ahead, her hands trembling, concealed underneath the foliage of the flowers.

\section{Conflicts of Interest}

The author declares she has no conflicts of interest.

\section{Author Affiliation}

1. Mercer University School of Medicine, Savannah, GA 